\title{
Profitability Analysis of Citronella Grass (Cymbopogon winterianus) Cultivation for Herbal Production: The Case of Wondo Genet District, Southern Ethiopia
}

\author{
Guta Bukero Zeyituna Abe Muluken Philipos \\ Ethiopian Institute of Agricultural Research, WGARC \\ Agricultural Economics Research Process, P.O.Box, 198, Shashemene, Ethiopia
}

\begin{abstract}
Aromatic plants are plants that possess aromatic compounds, most of which are essential oils which are volatile at room temperature. They can be used as raw materials for extraction of essential oils which, in turn, are used in the flavor and fragrance industries, as well as the sources of spices, herbs, and other natural products such as traditional medicines, pharmaceuticals, cosmetics, botanical pesticides, insect repellents, herbal teas/drinks, etc. Aiming to this, Wondo genet agricultural research center (one of the centers of Ethiopian institute of agricultural research)is responsible in doing research, promoting and coordinating aromatic, medicinal and bio energy plants at national level including other research activities on soil and water, livestock, forestry, and other food crops. In Ethiopia; other than the traditional aspect, the scientific aspect of aromatic and medicinal plants is not well known and little has been done on their economic contribution to households. Therefore Wondo genet agricultural research center has been done cost-benefit analysis for a selected aromatic grass namely Cymbopogon winterianus at wondo genet experimental site. The selected plant was planted based on its recommended spacing at wondo genet experimental site and the required data was collected. For the analysis net return to land (birr/ha) was used as a parameter. The analysis shows that, the selected aromatic grass provides the net return of which is $80417.32 \mathrm{birr} / \mathrm{ha}$ at fresh bio mass price of 1 birr. The NPV and BCR for Nardos grass was found to be: $76,858.5$ and 2.3 respectively.
\end{abstract}

Keywords: BCR, Benefit, Citronella grass/Cymbopogon winterianus, Cost and NPV

DOI: $10.7176 / \mathrm{JNSR} / 10-8-05$

Publication date: April $30^{\text {th }} 2020$

\section{Introduction}

Aromatic plants are plants that possess aromatic compounds, most of which are essential oils which are volatile in room temperature. They have traditionally been used as raw materials for extraction of essential oils which, in turn, are used in the flavor and fragrance industries, as well as the sources of spices, herbs, and other natural products such as traditional medicines, pharmaceuticals, cosmetics, botanical pesticides, insect repellents, herbal teas/drinks, etc. And they are plants that possess odorous volatile substances which occur as essential oil, gum exudates, balsam and oleoresin in one or more parts, namely, root, wood, bark, stem, foliage, flower and fruit.

\subsection{Production of Cymbopogon winterianus}

1. Cymbopogon Winterianus (Citronella grass): is an aromatic grass belonging to the family Gramineae and genus Cymbopogon. Citronella grass is a tufted perennial grass, the leaves of which

on distillation give a yellowish -brown essential oil with citrus odor. Citronella oil serves as a starting material for the extaction of geraniol and citronellal which can be converted into aroma chemicals such as citronellol , hydroxy citronellol, synthetic menthol and esters of geraniol. These find extensive use in soap, perfumery, and flavoring industries throughout the world. Soaps, soap flakes, detergents, household cleansers, insecticides and other technical products are often perfumed exclusively with this oil.

\subsection{Medicinal and Aromatic Plants World Market Volume}

Generally, in the period 1991-2003, the reported average annual global exports of medicinal and aromatic plant material amounted on average to 467,000 tones, or approximately $€ 1.06$ billion. The international trade was dominated by only a few countries: $80 \%$ of the worldwide imports were channeled to just 12 countries. Three international trade centers for botanicals could be recognized: the USA for North and South America, Hong Kong for Asia, and Germany for intra- European trade. Europe was responsible for one third of the annual global imports. Germany accounted for $12 \%$ of the total, and four other EU countries (France, Italy, the Unit United Kingdom and Spain) were among the major importers. In these countries, the raw material was mainly processed in each country's industry, and then sold as finished products either on the domestic market or exported (CBI market survey 2008; FAO, 2004). The leading suppliers were Germany, Poland, China and the USA. 


\section{Objectives}

1. To identify the cost and revenue of Citronella grass (Cymbopogon winterianus).

2. To provide information on cost and revenue of Citronella grass (Cymbopogon winterianus).

\subsection{Description of study area}

The analysis was conducted at Wondo Genet agricultural Research Center which is one of the centers of Ethiopian institute of agricultural research and is found in SNNPRS, in Sidama zone wondo genet woreda. It is located about $268 \mathrm{~km}$ south of Addis Ababa and $14 \mathrm{~km}$ south east of Shashemene. Its geographical location and altitude ranges from $38^{\circ} 37^{\prime} 13^{\prime \prime}-38^{\circ} 38^{\prime} 20^{\prime \prime}$ East and 7 $7^{\prime} 23^{\prime \prime}-7^{\circ} 5^{\prime} 52^{\prime \prime}$ North and 1760-1920 masl respectively. The center has been doing research activities on aromatic $\&$ medicinal plants and other crops, soil and water, livestock and forestry with focus on Aromatic and medicinal plants (Adugna et al 2010).

\subsection{Methodology of the analysis}

The study was conducted at Wondo Genet Agricultural Research Center (WGARC), Southern Nations, Nationalities and peoples region, Ethiopia in the Aromatic and Medicinal plants experimental field. Planting material used in the study was slip of citronella grass. To determine the production cost and benefit that would be obtained; the amount of labor cost for land clearing, plowing, watering and harvesting operations and cost of fertilizer and other material costs were recorded. In addition to this, yields per each harvest and overall total yields were recorded.

\subsubsection{Data analysis}

The data was analyzed by using simple cost accounting method. This analysis considers costs incurred and returns obtained during the economic life of the plant production. The analysis will help us to examine the economic contribution of Citronella grass (Cymbopogon winterianus). For this analysis net return to land (birr/ha), Net Present Value (NPV) and Benefit- Cost Ratio (BCR) was used for analysis (Guta et al., 2018).

To calculate total revenue (TR), total cost (TC), net present value (NPV), and Benefit cost ratio (BCR) the following formulas were used:

Total revenue (TR) $\mathrm{TR}=\mathrm{Q} * \mathrm{P}$

Where: TR: Total Revenue Q: Total quantity of fresh herb in $\mathrm{kg}$ P: Selling price per kg of fresh herb Total cost (TVC) $\mathrm{TC}=\mathrm{PC}+\mathrm{MC}+\mathrm{CP}+\mathrm{LC}$

Where: $\mathrm{TVC}=$ Total Variable cost $\mathrm{PC}=$ Plowing cost/first cost of plowing and harrowing $\mathrm{MC}=$ planting material cost $\mathrm{CP}=$ Land cleaning and leveling and cost of planting $\mathrm{LC}=$ Labor costs (labor cost of operation: watering, weeding and hoeing and harvesting).

$\mathrm{NR}=\mathrm{TR}-\mathrm{TC}$

Where: NR: Net return TR and TC are total revenue and total cost of production Net Present Value (NPV)

Net present value is simply the present worth of the cash flow stream.

\section{RESULTS AND DISCUSSION}

The fresh biomass yield of Citronella grass per hectare harvested for three (3) years is summarized in table 1 as follows.

Table 1. Quantity and frequency of harvest for selected aromatic grass (per ha for 3 years)

\begin{tabular}{|c|c|}
\hline Frequency & Nardos /Citronella grass biomass yield (in kg) \\
\hline $1^{\text {st }}$ & 2720 \\
\hline $2^{\text {nd }}$ & 14500 \\
\hline $3^{\text {rd }}$ & 18400 \\
\hline $4^{\text {th }}$ & 15300 \\
\hline $5^{\text {th }}$ & 16300 \\
\hline $6^{\text {th }}$ & 17200 \\
\hline $7^{\text {th }}$ & 9800 \\
\hline $8^{\text {th }}$ & 7000 \\
\hline $9^{\text {th }}$ & 16450 \\
\hline $10^{\text {th }}$ & 14960 \\
\hline $11^{\text {th }}$ & 6450 \\
\hline $12^{\text {th }}$ & 9700 \\
\hline Total & $148,780 \mathrm{~kg}$ \\
\hline
\end{tabular}

Source: experimental field data, 2011-13

As indicated above, the bio mass of Citronella grass fluctuates i.e. it increases till 3rd harvest and decreases in the $4^{\text {th }}$ harvest and again increases in the $5^{\text {th }}$ harvest. The first harvesting time after planting for Citronella/Nardos grass was 3 months and the rest consecutive harvests were made after 2 months. 


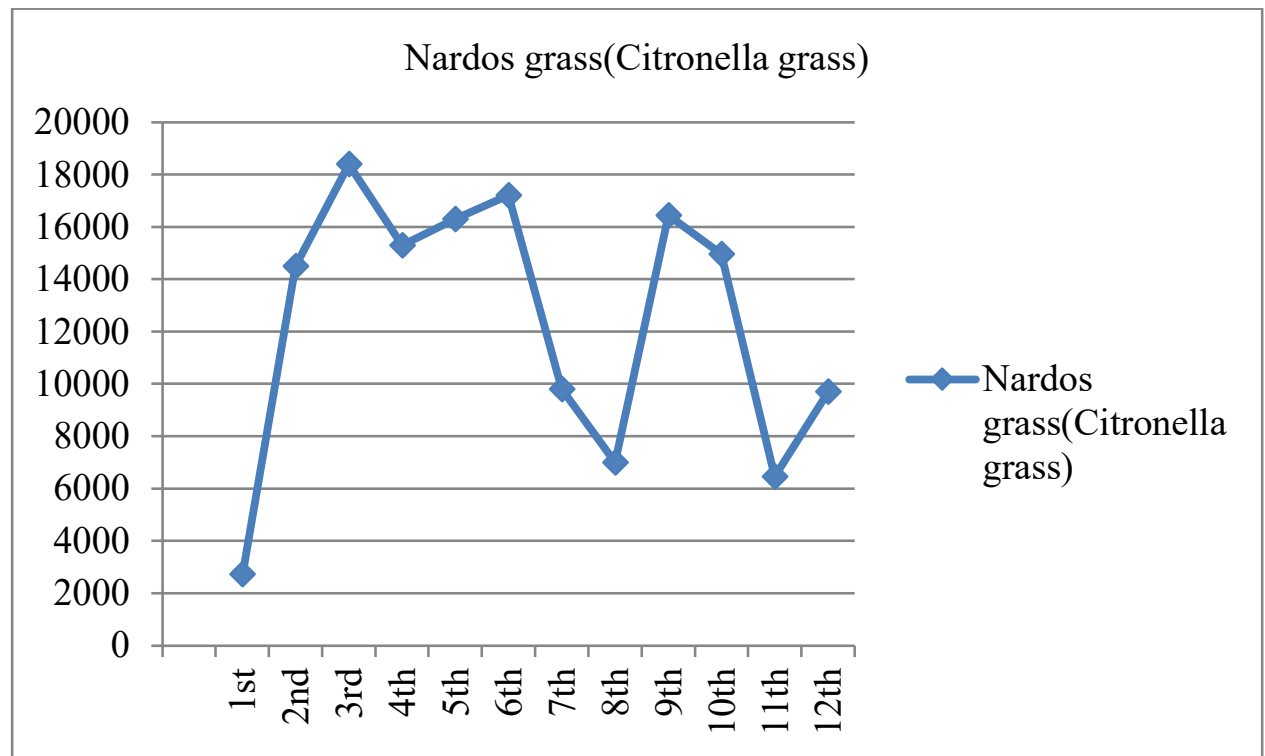

Figure 1: Quantity and Frequency of Harvests for Selected Aromatic Grasses Source: experimental field data, 2011-13

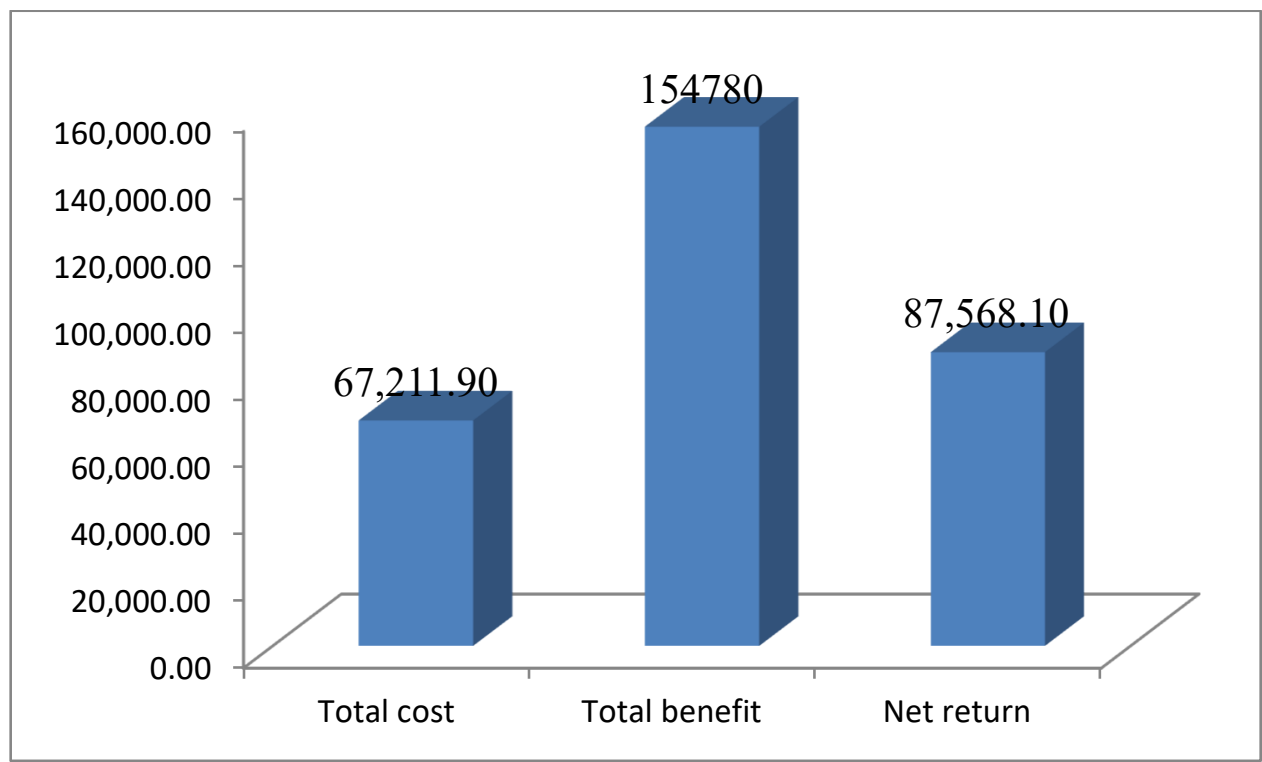

Figure 2: Summary of cost and benefit of citronella grass Source: experimental field data, 2011-13

On the other hand, of the different costs of cultivating aromatic grasses weeding and hoeing cost share the largest production cost (on average $30 \%$ of the total production cost) in the case of Wondo Genet Agricultural research center. But this may vary from place to place depending on the severity of weed in the area.

Table 2. Returns of citronella grass in its individual economic life

\begin{tabular}{ccccc}
\hline \multirow{2}{*}{ Item } & \multicolumn{4}{c}{ Citronella grass } \\
\cline { 2 - 5 } & year 1 & Year2 & Year 3 & Total \\
\hline $\begin{array}{c}\text { Production in } \\
(\mathrm{kg})\end{array}$ & 67220 & 65410 & 22150 & 154780 \\
$\begin{array}{c}\text { Price/kg(in Birr) } \\
\text { Total Revenue }\end{array}$ & 1 & 1 & 1 & 1 \\
\hline
\end{tabular}

$1 \mathrm{USD}=17.5 \mathrm{ETB}$

Source: experimental field data, 2011-13 
Table 3: Costs from cultivating Citronella grass

\begin{tabular}{|c|c|c|c|c|}
\hline \multirow[t]{2}{*}{ Particulars } & \multicolumn{3}{|c|}{ Economic life (in years) } & \multirow[t]{2}{*}{ Sub total } \\
\hline & 1 & 2 & 3 & \\
\hline \multicolumn{5}{|l|}{ Fixed cost: } \\
\hline $\begin{array}{l}\text { Rental value of a hectare of land @ } 95000 \text { Birr for one year } \\
\text { for } 3 \text { years }\end{array}$ & 5000 & 5000 & 5000 & 15000 \\
\hline $\begin{array}{l}\text { Rental value of tractor @1700Birr/ha ( For Plowing and } \\
\text { disking) }\end{array}$ & 1700 & & & 1700 \\
\hline \multicolumn{5}{|l|}{ material cost: } \\
\hline Seedling cost@10 birr/kg@90kg/ha & 900 & & & 900 \\
\hline $\begin{array}{l}\text { Fertilizer cost @8.4 birr } / \mathrm{kg} @ 50 \mathrm{~kg} / \mathrm{ha} \text { for } 5 \text { harvest for } \\
1 \text { st year , } 5 \text { harvest for 2nd year and } 5 \text { harvest for 3rd year }\end{array}$ & 2100 & 2100 & 2100 & 6300 \\
\hline \multicolumn{5}{|l|}{ Labor charge for: } \\
\hline land preparation@14.7 birr/man-day@62 man-days/ha & 911.4 & & & 911.4 \\
\hline $\begin{array}{l}\text { seedling preparation and planting@14.7 birr/man-day @ } \\
97 \text { man-days/ha }\end{array}$ & 1426 & & & 1426 \\
\hline $\begin{array}{l}\text { Watering@14.7 birr/man-day @ } 17 \text { man-days } / \text { ha } / \text { single } \\
\text { round for } 15 \text { round in } 1 \text { st year , @14 man-days } / \text { ha } / \text { single } \\
\text { round for } 15 \text { round in } 2 \text { nd year and @ } 7 \text { man-days } / \text { ha } / \text { single } \\
\text { round for } 12 \text { round in 3rd year }\end{array}$ & 3748.5 & 3087 & 1234.8 & 8070.3 \\
\hline $\begin{array}{l}\text { Weeding and hoeing@14.7 birr/man-day @16 man- } \\
\text { days } / \text { ha/single round for } 22 \text { round in } 1 \text { st year, @ } 10 \text { man- } \\
\text { days } / \text { ha/single round for } 13 \text { round in } 2 \text { nd year and @ } 8 \\
\text { man-days } / \text { ha } / \text { single round for } 15 \text { round in 3rd year }\end{array}$ & 5174.4 & 1911 & 1764 & 8849.4 \\
\hline $\begin{array}{l}\text { Harvesting@14.7 birr/man-day @22 man-days/ha/single } \\
\text { round for } 5 \text { round in } 1 \text { st year, @ } 36 \text { man-days } / \text { ha/single } \\
\text { round for } 5 \text { round in } 2 \text { nd year and @ } 40 \text { man-days/ha/single } \\
\text { round for } 5 \text { round in } 3 \text { rd year }\end{array}$ & 1617 & 2646 & 2940 & 7203 \\
\hline $\begin{array}{l}\text { Fertilizer application @ } 14.7 \text { birr } / \text { man-day @14 man- } \\
\text { days } / \text { ha } / \text { single round for } 5 \text { round in } 1 \text { st year, } 12 \text { man- } \\
\text { days } / \text { ha } / \text { single round for } 5 \text { round in } 2 \text { nd year and } 12 \text { man- } \\
\text { days } / \text { ha } / \text { single round for } 5 \text { round in } 3 \text { rd year }\end{array}$ & 1029 & 882 & 882 & 2793 \\
\hline $\begin{array}{l}\text { Fertilizer application @ } 14.7 \text { birr } / \text { man-day @24 man- } \\
\text { days } / \text { ha } / \text { single round for } 5 \text { round in 1st year, @24 man- } \\
\text { days } / \text { ha } / \text { single round for } 5 \text { round in } 2 \text { nd year and @24 man- } \\
\text { days } / \text { ha } / \text { single round for } 5 \text { round in 3rd year }\end{array}$ & 1764 & 1764 & 1764 & 5292 \\
\hline Total cost of herbage cultivation & 25370.3 & 17390 & 15684.8 & $58,445.1$ \\
\hline Miscellaneous costs (15\%) & 3805.5 & 2608.5 & 2352.7 & $8,766.8$ \\
\hline Overall cost of herbage cultivation & 29175.8 & 19998.5 & 18037.5 & $67,211.9$ \\
\hline
\end{tabular}

Table 4: The Financial feasibility for Nardos / Citronella Grass

\begin{tabular}{lllll}
\hline \multicolumn{1}{c}{ Items } & \multicolumn{2}{c}{ Economic Life ( in Years) } & Total \\
\hline & \multicolumn{1}{c}{$\mathbf{1}$} & \multicolumn{1}{c}{$\mathbf{2}$} & \multicolumn{3}{c}{$\mathbf{3}$} \\
Total fresh biomass yield & 67220 & 65410 & 22150 & 154,780 \\
Total value & 67220 & 65410 & 22150 & 154,780 \\
Overall cost of herbage cultivation & 29175.8 & 19998.5 & 18037.5 & $67,211.9$ \\
Net return from herbage cultivation & 38044.1 & 45411.5 & 4112.5 & $87,568.1$ \\
Discounted total value & 61953.9 & 55562.9 & 17341.4 & $134,858.2$ \\
Discounted overall cost of herbage cultivation & 21841.9 & 13957.9 & 12083.5 & $57,999.7$ \\
\hline NPV & & & & $\mathbf{7 6 , 8 5 8 . 5}$ \\
BCR & & & & $\mathbf{2 . 3}$ \\
\hline
\end{tabular}

NB: - The fresh biomass price of Citronella grass is $1 \mathrm{birr} / \mathrm{kg}$

\section{CONCLUSIONS}

Even if the price of this aromatic grass is not set by the market, at the current price production of aromatic and medicinal plant is profitable. The major production cost for this aromatic grass is weeding and hoeing but it may vary from place to place. 
Though this aromatic grass is profitable, it may doesn't mean that it is economically viable. Because it is too difficult to study profitability comparison between this selected aromatic grass and major crops grown in the surrounding districts (i.e., wondo and wondo genet) because of price dynamism for those major crops due to their market existence.

\section{ACKNOWLEDGEMENT}

We would like to Acknowledge Wondogenet Agricultural Research Center Aromatic and Medicinal Research Program for its financial support. Next our deepest gratitude goes to our field assistant Sofonias Admasu and Gezahegn Erkeno for their unreserved contribution during data collection and recording in the period of cultivation.

\section{REFERENCES}

Adugna N., Zenebe M., and Kefyalew L., February 2010 site characterization of Wondo genet agricultural research center.

CBI market survey, October 2008 The market for natural ingredients for Pharmaceuticals in the EU.

Department of agriculture Directorate: Plant Production June 2009 Rosemary Production.

Endashaw Bekele, December 2007 Study on Actual Situation of Medicinal Plants in Ethiopia

Joy, P.P., Thomas, J., Mathew, S., Jose, G. and Joseph, J. 2001. Aromatic plants. Tropical Horticulture Vol. 2. (eds. Bose, T.K., Kabir, J., Das, P. and Joy, P.P.). Naya Prokash, Calcutta, pp.633-733

Lammia Sharmin, September 2004 Cultivation prospect of medicinal plants inBangladesh: experiences from Natore

Mahabir p. gupta, (2011). Perspectives of medicinal and aromatic plants and their products in the emerging globalization era Presented at the Expert Group Meeting on Priority Needs of Developing Countries in the Field of MAPS held in Trieste, Italy, 21 - 22 February 2011

World health organization 2011 the world medicines situation traditional medicines: global Situation, issues and challenges 